\title{
Operation Mechanism of Industry and Academia Cooperation College
}

\author{
Yuhuang Zheng ${ }^{1,2}$ \\ 1. Academic Affairs Office \\ Guangdong University of Education \\ 2. Department of Physics and Information Engineering \\ Guangdong University of Education \\ Guangzhou, China \\ zhyhaa@126.com
}

\begin{abstract}
China's economy is growing, and Chinese higher education is developing with rapid acceleration. Chinese higher education faces a barrier to promoting university-industry collaboration now. The traditional teaching methodologies are not suitable for industry requirements. Industry and Academia Cooperation College (IACC) is a new way to establish industryacademic linkages and to support universities in China in improving their engineering education. Operation mechanism could influence the propensity and the scope of universityindustry collaboration in IACC. This paper focuses on the operation mechanism of IACC. Examinations of regional development and academia-business cooperation of IACC are discussed. Based on existing research and practice, the operation mechanism of IACC is addressed. The content of this paper provides a new way of effective cooperation Model in IACC.
\end{abstract}

Keywords_-industry; college; cooperation; academia

\section{INTRODUCTION}

The academic system in the mainland of China is forced to respond to economic and industrial development. Academic colleges and universities are expected to cultivate talents who can apply theoretical knowledge and process complex tasks. There is a gap between traditional teaching methodologies and enterprise-oriented education. Some academic institutions and companies try to bridge the gap. Industry and Academia Cooperation College (IACC) is a new way. Universities need collaborating with industry include the improvement of teaching methodologies and access to cases or scenarios from industry. The firms that collaborate with universities could gain access to the university's equipment and reduce research and development risks. Despite the university-industry collaboration is growing, but there are still many barriers to persist. Firms seek short-term economic benefits and intellectual property rights. For this reason, Chinese universities are not active in collaborations with industry. The operation mechanism of IACC has gradually been attached importance to university-industry collaboration. The operation mechanism should solve the challenges of bridging the industry-university gap. The operation mechanism of IACC should make universities attractive as industry excellent partners and support seamless interactions. The IACC should build a platform of industry-university collaboration and ensure a stable environment for long-term strategic industry-university partnerships to be flourishing.[1].

\section{OPERATION MECHANISM OF IACC}

Although the research motives of universities and private companies have traditionally been contradictory, universities have become more enterprise-oriented and the firms are realizing that academic research has the need to support applied research. Emerging research areas are becoming progressively interdisciplinary, encompassing Science, Technology, Engineering, Arts, Mathematics. The college is guided by the needs of enterprises and strives to build a community to promote industry-university collaboration[2]. The content of university-industry collaboration includes jointly develop training objectives and training programs, jointly build courses and development courses, jointly build laboratories and practice bases, cooperate with training teachers, and cooperate with research to encourage industrial development. Enterprises fully participate in teaching and promote the close integration of talent cultivation and industrial needs. (Fig.1).

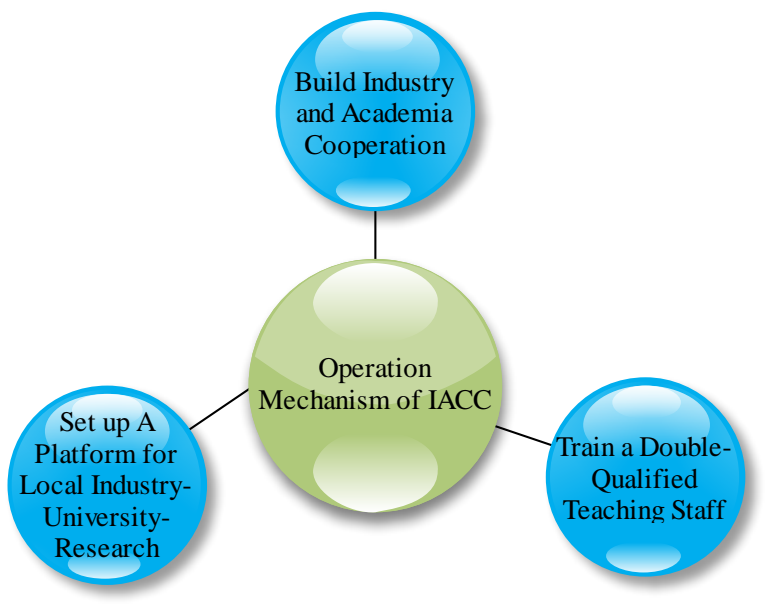

Fig. 1. Operation mechanism of IACC.

According to the collaboration, IACC can have a variety of operation Models: the first type is the deep cooperation between the university and the enterprise; all majors offered by the IACC are closely connected with the industrial chain of the 
cooperative enterprise and its industry; the cooperative enterprise supports the construction of the school and participates in the process of running the school. It even replaced the existing secondary colleges with IACC. The second type of IACC offers some majors for deep cooperation with cooperative enterprises, and both the university and the enterprise conduct talent training through co-construction of industrial classes. The third type of IACC is mainly for industries and enterprises, aiming to create a platform for the integration of industry and education and the collaborative education between schools and enterprises.[3]

\section{A. Building Industry and Academia Cooperation}

IACC connects the industry chain within the service industry and plans and manages multiple related majors in the same industry chain to strengthen the cooperation between school and enterprise cooperation and professional group management. In the process of construction, IACC shares its high-quality teaching resources through the demonstration and leadership of the professional group, promotes the development of other professions, and promotes the comprehensive advancement of the school's professional construction. IACC establishes industry-specific professional teaching quality standards and improves the teaching quality assurance system.[4]

\section{B. Setting up A Platform for Local Industry-University- Research}

The establishment of the IACC is inseparable from local development, and the IACC's professional and talent training model should be matched with the overall planning of regional development. When formulating the talent training plan, the IACC should consider the needs of the advantageous industries and markets in the region, reform the curriculum teaching and curriculum system in a targeted manner, and train talents that are compatible with the development of the region. At present, the national strategy of the Guangdong-Hong Kong-Macao Greater Bay Area provides new opportunities for universities in Guangdong Province. This national strategy clarifies the positioning of universities, continually optimizes them, develops a talent training model that meets the needs of regional development, and improves regional development capabilities.

Universities need to accelerate their integration into local economic and social development, build a platform for cooperation between industry, academia and research in service areas, and deepen the strategic cooperation with local industry leading enterprises, innovative schools and school enterprises through the construction of industrial colleges. University and enterprises need to improve the cooperation Model, implement the docking mechanism, build the general technology research and development center service industry, and promote the transformation and industrialization of scientific and technological achievements. Industrial enterprises that cooperate with IACC carry out scientific research, actively explore new ways of radiation diffusion and industrialization of advanced technologies, and continuously improve the ability of schools to serve local economic and social development.[5]

\section{Training a Double-Qualified Teaching Staff}

We will intensify the transformation of teachers on campus and send full-time teachers to industrial enterprises served by IACC for training, temporary work and practical training in a planned way. We should strengthen the classified management of teachers, reform the teacher evaluation system, set up different types of teachers' posts in a reasonable way, and guide teachers to transform into double-qualified teachers. We will improve the mechanism for the introduction, certification and use of double-qualified full-time and part-time teachers, introduce senior experts, technical backbones and management experts from industrial enterprises as full-time and part-time teachers, and employ senior engineering and technical personnel of industrial enterprises served by IACC as enterprise engineering teachers to teach students.

\section{TALENT TRAINING MODEL OF IACC}

The IACC supports technical and management talents to teach in colleges and universities. It should set up several positions for enterprise members. IACC gives priority to the employment of "double-qualified" teachers. IACC carries out joint teaching by university-enterprise tutors to build a "doublequalified" teaching team (Fig.2.). The IACC will be built into a "double-qualified" teacher training base. The principle of the establishment of IACC is to integrate related majors and focus on teaching industry training, scientific and technological research base on the industrial needs and development direction of the region and the entry point of industrial needs. The construction of IACC includes industry-oriented talents training, double-qualified teachers training, practical practice and training, students' innovation and entrepreneurship, enterprise achievement transformation, new product research and development. IACC can play a key role in the absorbing and disseminating advanced technology.

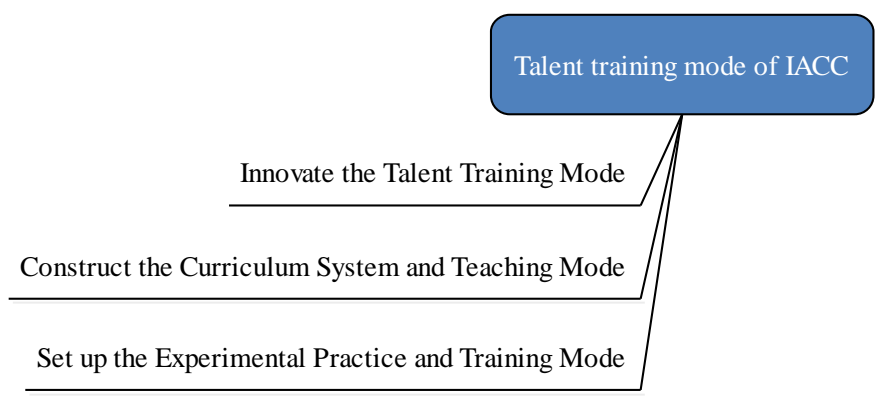

Fig. 2. Talent training Model of IACC.

\section{A. To Innovate the Talent Training Model}

The IACC needs to study the large-scale talent demand and talent quality requirements of the service industry enterprises and form a summary report of the industry talent demand. The IACC is guided by the demand for employment services and the improvement of professional competence. With the continuous improvement of students' learning ability, the IACC deepens the integration of teaching, industry-university cooperation, and jointly develops talent training programs for industry colleges. IACC and the enterprise jointly establish a talent training system and develop curriculum resources, 
implement a training process, jointly conduct training quality evaluation, and reconstruct talent training norms, curriculum systems, teaching contents, teaching methods, and student academic evaluation methods. IACC establishes a talent training model. In the process of improving practical ability, it takes the lead in applying professional certification methods to achieve the integration of vocational courses and industrial needs, curriculum content and professional standards, and the integration of teaching process and production process.[6]

\section{B. To Construct the Curriculum System and Teaching Model}

Most university teachers currently lack industry experience. The IACC curriculum must focus on helping solve the scientific and technical challenges that the company cares about. This means breaking the institutional barriers within the university and attracting teachers with industry experience. The IACC needs multidisciplinary individuals who are instructors. More attention should be paid to the cultivation of students' application ability and innovation and entrepreneurship ability, and the integration of professional basic courses, main courses, core courses, professional skills application and experimental practice courses, to form an industry-oriented curriculum group or curriculum module highlighting the cultivation of practical ability. According to the needs of industrial enterprises served by IACC, curriculum reform should be carried out, curriculum system should be designed, curriculum structure should be optimized, curriculum content should be aligned with professional standards, and several university-enterprise cooperation courses should be constructed. IACC works with industrial companies to implement a student-centered projectbased teaching model centered on practical problems. IACC reforms the current practical teaching content and methods and regards industrial enterprise technology innovation projects as an important carrier for industrialized personnel training, and regards the frontier needs of industrial enterprises as the source of graduation design topics. The subject construction should be guided by industry and academia, and the traditional curriculum and teaching methods should be reformed. By making use of the resources and conditions of the IACC, the traditional majors should be built into the industry-oriented majors. Major setting is consistent with industrial demand and supports the trend of the industry.

\section{To Set up the Experimental Practice and Training Model}

The knowledge education system and the experimental training and internship environment are constructed According to the requirements of combining work with study and integrating knowledge with practice, and according to the real technology and process of production and service of industrial enterprises served by IACC. The IACC coordinates various practical teaching resources and builds a professional experimental teaching center with open resources and efficient operation. Through the introduction of enterprise research and development bases, IACC will build the functions of production, education and research into a large-scale experimental practice center and training base integrating university, enterprise, industry and education. Each IACC shall build several high-level off-campus practice and training bases.[7]
It encourages enterprises to stay in the IACC. Advantageous enterprises should share the productive training to the IACC and introduce the real scene of industrial production practice into teaching. With the development needs of enterprises, the IACC should provide suitable projects, equipment, funds, internship positions, organize social practice and internship of students. The practical training of IACC uses entrepreneurship training topics, and enterprise engineers are arranged to serve as students' innovation and entrepreneurship tutors to guide the project. The IACC should select enterprise projects as student's graduation design, graduation thesis topics, and the implementation of the real topic.

\section{CONCLUSION}

The IACC's reform of the talent training model for different Models mainly includes promoting industry-university cooperation and promoting cooperation between enterprises and the government. In the field of engineering education, IACC has vigorously promoted transformational development and innovation and entrepreneurship education and achieved results. The IACC pays attention to the innovation of the talent training model and should not blindly pursue quantitative development. IACC should be based on educational standards, aiming at deepening the combination of production, study and research, and building sustainable principles as the basic principle, with the service level of teaching, the construction of teaching staff and the promotion of services as the basic principles. Disciplinary construction and student talent training model innovation are the fundamental tasks of the IACC.

At present, there are some problems in the integration of education, science and production, such as how to establish an industry-university cooperation mechanism, how to meet the needs of local economic and social development and enterprise technology innovation, and how to formulate talent training programs with the needs of industry talents. This paper mainly focuses on the above three issues. The research results of this paper have a certain significance for industrial colleges to make full use of economic and political resources, give full play to their professional advantages, and deepen the cooperation of industry, university and research according to the characteristics of the school. The creation of the IACC breaks the traditional academic gap and promotes innovative curriculum teaching models.

\section{ACKNOWLEDGMENT}

This article is one of the stage achievements of the following projects: 2017 Research and practice of new engineering talents training of Electronic Information Engineering Specialty; 2017 the education project of university innovation and entrepreneurship in Guangzhou (No. 2017192201); 2017 Quality project of Guangdong University of Education (No. 2017zdzz01); 2018 Innovation and Entrepreneurship Education Program of Guangdong University of Education (No. 2018sfjd02); 2016 Guangdong Provincial Key Laboratory of Precision Equipment and Manufacturing Technology project (No. PEM201604). 


\section{REFERENCES}

[1] S. Boonsri, K. Tangdhanakanond, and S. Kanjanawasee, "A Development of the Knowledge Competency Model for Vocational Technical Teachers," Advanced Science Letters, vol. 24, pp. 4550-4553, Jun 2018.

[2] Y. H. Chien and P. Y. Chu, "The Different Learning Outcomes of High School and College Students on a 3D-Printing STEAM Engineering Design Curriculum," International Journal of Science and Mathematics Education, vol. 16, pp. 1047-1064, Aug 2018.

[3] S. Chopra and K. M. Deranek, "Efficiently Teaching Engineering and Technology Students through Effective College-Industry Partnerships," Journal of Engineering Technology, vol. 35, pp. 10-15, Sep 2018.
[4] A. Probst, G. Schachinger, G. Kalteis, and A. Fischer, "New Technologies as a Driver for Business Success," International Journal of Engineering Pedagogy, vol. 9, pp. 102-112, 2019.

[5] K. Karthiekheyan, I. Ahmed, and J. Jayalakshmi, "Pair Programming for Software Engineering Education: An Empirical Study," International Arab Journal of Information Technology, vol. 15, pp. 246-255, Mar 2018.

[6] T. Khongrangjem et al., "A study to assess the knowledge and practice of fast food consumption among Pre-University students in Udupi Taluk, Karnataka, India," Clinical Epidemiology and Global Health, vol. 6, pp. 172-175, Dec 2018.

[7] D. Y. Tadeus, Yuniarto, and T. Yuwono, "Design and Implementation of SCADA Training Module: Human Machine Interface (HMI) Based on Open Software," Advanced Science Letters, vol. 24, pp. 9595-9598, Dec 2018. 